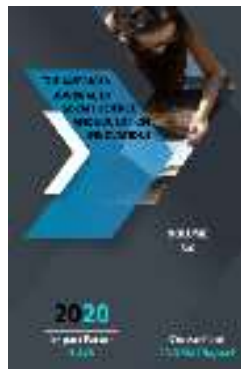

\section{Formation Of The Content Of Educational-Methodical Complexes In The System Of Professional Development}

\author{
Jumanazarov Sirojiddin Salaydinovich \\ Phd, Tashkent City Regional Center Of Training And Retraining The Personnel Of Public \\ Education, Tashkent, Uzbekistan
}

Journal Website: http://usajournalshub.c om/index,php/tajssei

Copyright: Original content from this work may be used under the terms of the creative commons attributes 4.0 licence.

\title{
ABSTRACT
}

In this article we discussed, one of the main problems in the system of professional development is considered the formation of the content of educational and methodological complexes in the direction of innovative pedagogical activity of students

\section{KEYWORDS}

Listener, innovation, educational and methodological support, knowledge, skills, qualifications, pedagogical support

\section{INTRODUCTION}

The innovation activity of the educator is an indispensable part of the educational process. The introduction of innovation in education makes it possible for educators to adapt to changing conditions and use non-standard methods during lessons. Modernized education in the present day requires new views and approaches from each educator, not limited to old and tested methods. The educator should be able to attract them to the educational process with the aim of giving knowledge to the students and educating the growing younger generation with the embodiment of creativity, but also achieve effective results. Bunda's innovative methods and approaches will not only help make the course process interesting, but will also have prospects for the development of educational content. 
In this article we discussed, the stages of creating educational-methodical complex "Pedagogical software tools in the educational process", which is considered one of the educational modules in the direction of Information Technology in the direction of innovative pedagogical activity of listeners in the system of professional development, and the issues of formation of content are considered [1-3].

\section{MATERIALS AND METHODS}

Based on the results of the monitoring conducted in the process of improving the skills of the employees of the public education system for several years, this educationalmethodological work was created on analytical materials on filling the gaps in knowledge and skills of listeners in the direction of Information Technology and directing them to innovative pedagogical Activity [4]. In addition, the following rules were applied in the creation of this educational and methodical complex:

- Develop your audience's existing knowledge and skills support an understandable and easy to read textual view;

- To bring interesting schemes, diagrams, various drawings and tables that will help the audience develop their knowledge related to the subject of science;

- To bring practical exercises and control questions in order to further develop the acquired knowledge and skills of the audience;

- $\quad$ To bring assignments to the audience to find solutions to problematic situations.

- In order to improve the quality of the created educational and methodological complex, attention is paid to the following:
- $\quad$ Taking into account the existing knowledge and practical experience and needs of the audience;

- $\quad$ Taking into account the opportunities of all regional centers in the Republic, the circle of listeners, that is, the conditions and abilities of their professional development into account in the creation of the educational-methodical complex;

- $\quad$ Considering that the language of the educational-methodical complex corresponds to the age of the audience;

- $\quad$ The basis of the science curriculum in the creation of educational and methodological complex;

- Attention was also paid to the professional activity of the created educational-methodical work, directing the audience to activity, innovative pedagogical activity on the basis of specific goals and tasks.

- Shular in addition, it is based on the following criteria tested in the creation of educational and methodological complex:

- $\quad$ To compose the text of the lessons in an understandable and logical way, to facilitate the learning process, to place on the pages of the teaching methodology using illustrations and drawings;

- Writing the text in an understandable, fluent and interesting form, taking into account the qualification directions of the audience, using examples that relate to their experience;

- Theoretical and practical training in the educational-methodical complex and a brief description of the relevant knowledge and a deep connection with the summary section; 
- Taking into account the sociopsychological needs of the audience in various regional centers of the Republic;

- Writing the educational-methodical complex in the form that fully corresponds to the science program and covers it on a scan;

- $\quad$ Ensure the accuracy, color consistency, safety of the content;

- To pay attention to the size of educational-methodical paper, the use of colors in place, the quality of paper and the cover;

- The criteria such as the inclusion of assignments that motivate the audience to work on the given material and innovative pedagogical activity were met.

\section{RESULT AND DISCUSSION}

On the basis of studying and analyzing the competency of the listeners in the field of information and communication technologies in the existing regional centers of the Republic, the topics of this educational and methodological complex have been formed, and the current scientific and technical development, interdisciplinary integration and features of modern education have also been taken into account in the complex. The goal is to develop competences for the creation of electronic educational resources using pedagogical software in the professional activities of the audience in the process of professional development. Attention was also paid to the fact that the existing knowledge of the audience can be relied on and on this basis form an integral sequence of topics.

Therefore, in the theoretical part of the educational and methodological complex, the basic concepts about pedagogical software in the educational process are given, and the necessary technical tools are fully introduced from the theoretical side.

In practice, the iSpring program, which aims to develop the skills and skills of creating interactive electronic tests and 3D books by using the opportunities of the author's program in order to increase the effectiveness of educational processes, and which is convenient for the formation of innovative activity of the audience, is selected for the creation of multimedia electronic learning materials.

\section{CONCLUSION}

The content of the educational and methodological complex is formed on the basis of innovative approaches as described above, which serve as the basis for the orientation of the audience to innovative pedagogical activity in the system of Professional Development, effective use of information and communication technologies in their professional activity.

The content of the educational and methodological complex "pedagogical software tools in the educational process", created on the basis of the above rules and criteria, is aimed at ensuring the independent and free thinking of the audience, the development of their existing knowledge, perfection, Independent Education, the development of skills in search of new knowledge.

\section{REFERENCES}

1. Jumanazarov S.S. Innovations and modern pedagogical technologies in the education system : materials of the $X$ international scientific conferenceence on February 2021, 2020. - Prague: Vědecko vydavatelské centrum "Sociosféra-CZ", 2020. - 194p. ISBN 978-80-7526-451-0. 
2. Jumanazarov S.S. The role of information and communication technologies in the preparation of listeners for innovative pedagogical activity. Materials of the international scientific-practical conference" improving the quality of modern continuous education: innovation and prospects". Tashkent. 2020.

3. Jumanazarov S.S. In modernized education, the issue of preparing listeners for innovative activities. Materials of the international scientific-practical conference" the combination of integration and innovative thinking in the system of professional development: problems and solutions". Kashkadarya, 2020.

4. Maxkamov A.A., Jumanazarov S.S., Masharipov M.P. Educational-methodical on the module "Usage of modern information and communication technologies in the educational process". Tashkent, 2020. 